\title{
Hydroxyapatite suspensions as precursors of pieces obtained by gelcasting method
}

\author{
S. Padilla, R. García-Carrodeguas ${ }^{1}$, M. Vallet-Regi* \\ Departamento de Química Inorgánica y Bioinorgánica, Facultad de Farmacia, \\ Universidad Complutense de Madrid, 28040 Madrid, Spain
}

Received 5 January 2003; received in revised form 5 June 2003; accepted 22 June 2003

\begin{abstract}
The aim of this work was to prepare slurries of hydroxyapatite (OHAp) with a high content of solids, which is necessary for shaping pieces by the gelcasting method. For this purpose different studies were carried out using powders of OHAp calcined at temperatures ranging between 600 and $1200{ }^{\circ} \mathrm{C}$ and several dispersants. Surface area, porosity and chemical composition of OHAp powders played a fundamental role in the viscosity of slurries. The highest concentration of solid was obtained with OHAp calcined at $1200{ }^{\circ} \mathrm{C}$. The best dispersant was selected in a first stage, by electrophoretic measurements and sedimentation studies and, finally, by rheological measurements. The concentration of dispersant which provides the minimum viscosity, depended on the calcination temperature of the OHAp. A great increased of viscosity took place for time of slurries preparation higher than 30 min. Milling of powder for $20 \mathrm{~h}$ was necessary to improve the rheological behaviour of the slurries. Finally, ceramic bodies were prepared from fluid slurries containing 60 vol. $\%$ of solids and the mechanical properties were evaluated.
\end{abstract}

(C) 2003 Elsevier Ltd. All rights reserved.

Keywords: Apatite; Biomedical applications; Gelcasting; Shaping; Suspensions

\section{Introduction}

Calcium phosphate ceramics, mainly hydroxyapatite (OHAp), have been widely used in the replacement of the bone tissue. ${ }^{1-4}$ OHAp shows excellent biocompatibility with hard tissues and directly bonds to bone. However, its clinical application has been limited due to its low mechanical reliability and to the difficulty to obtain pieces with complex shapes similar to bone defects.

Janney and co-workers ${ }^{5,6}$ developed a new method, named gelcasting, which allows to obtain pieces with complex shapes and high mechanical strength. This method use slurries of ceramic powders with high solid content and an aqueous solution of monomers as the dispersing vehicle. By in situ polymerisation of the dissolved monomers, a macromolecular network is created

\footnotetext{
* Corresponding author. Tel.: +34-91-3941861; fax: +34-913941786.

E-mail address: vallet@farm.ucm.es (M. Vallet-Regí).

1 Permanent address: Centro de Biomateriales, Universidad de La Habana, A.P. 6130, 10600, Cuba.
}

that binds ceramic particles together, thus producing green bodies with high density and strength, able to be machined by conventional methods. Because of the high solid content and the use of bifunctional monomer, the green bodies only contain a small amount of volatile binder, thus, the risks of cracking and shrinkage during drying and sintering are minimised. This method has been successfully applied to ceramics such as alumina,${ }^{7-9}$ silicon nitride, ${ }^{10}$ rutile, ${ }^{11}$ silicon carbide ${ }^{12,13}$ and alumina-zirconia composites. ${ }^{14,15}$ In addition, this method has been combined with a foaming method to produce porous OHAp ceramics. ${ }^{16}$

Gel casting requires slurries with good flow properties and high solid content (at least 50 vol.\%). However, only solid contents lower than 50 vol.\% have been achieved in most of the previous reports on the preparation of slurries of OHAp. ${ }^{16-19}$

In order to obtain dispersed slurries with high solid content it is necessary to study the different factors affecting their stability and rheology, such as the characteristics of the dispersing medium, type and amount of dispersant, powder characteristics (specific surface area, chemical composition and size distribution of the 
powder particles), preparation time of slurries and solid content.

In this work the above-mentioned aspects were studied using powders of OHAp calcined at temperatures ranging between 600 and $1200{ }^{\circ} \mathrm{C}$ and several dispersants. Slurries with high content of solid (up to 60 vol.\%) and good fluidity were investigated.

\section{Materials and methods}

\subsection{OHAp preparation and characterisation}

OHAp was prepared by neutralising an aqueous slurry of $\mathrm{Ca}(\mathrm{OH})_{2}$ (Riedel-deHaën) with a solution of $\mathrm{H}_{3} \mathrm{PO}_{4}$ (Merck). This was slowly added to the $\mathrm{Ca}(\mathrm{OH})_{2}$ suspension until the $\mathrm{pH}$ reached 7.1 and the mixture was stirred for $30 \mathrm{~min}$. The reaction was carried out at $90{ }^{\circ} \mathrm{C}$. The HA slurry was aged for $24 \mathrm{~h}$ at room temperature, decanted and vacuum filtered. The cake was dried at $105{ }^{\circ} \mathrm{C}$ for $12 \mathrm{~h}$ and afterwards, the solid was ground in a vibrating mill. The so obtained OHAp was characterised by XRD in a Philips X'Pert MDP diffractometer $\left(\mathrm{Cu} K_{\alpha}\right.$ radiation) and FTIR in a Nicolet Nexus spectrometer. Quantitative analysis of $\mathrm{Ca}$ and $\mathrm{P}$ were performed by X-ray fluorescence on a S4 EXPLORER, Brucker AXS. The results of the characterisation showed that the OHAp obtained was a type $\mathrm{B}$ carbonateapatite, with partial subtitution of $\mathrm{CO}_{3}^{2-}$ by $\mathrm{PO}_{4}^{3-}$ and a $\mathrm{Ca} / \mathrm{P}$ molar ratio of 1.68 .

The initial OHAp was calcined at temperatures varying from 600 to $1200{ }^{\circ} \mathrm{C}$ during $1 \mathrm{~h}$, in order to study the influence of calcination temperature on the properties of OHAp powders and consequently on their slurries.

The phase composition of the OHAp powders calcined at different temperatures was analysed by XRD. Specific surface area was calculated using the BET method from $\mathrm{N}_{2}$ adsorption isotherm obtained in a Micromeritics ASAP2010 analyser. Mercury intrusion porosimetry (Micromeritics AutoPore III) was used to study the pore size distribution. The morphology of the powder was studied by scanning electron microscopy (SEM) using a Jeol 6400 Microscope-Oxford Pentafet super ATW system. Particle size distribution was determined by sedimentation using a Sedigraph Micromeritics 5100 Size Analyser.

\subsection{Dispersants}

The name and composition of dispersants studied are shown in Table 1. All of them had anionic character, because this kind of dispersant seems to be more effective to stabilise OHAp slurries. ${ }^{17}$ The best dispersant was selected on the basis of electrophoretic, sedimentation, and viscosity measurements.
Table 1

Trade name and composition of the studied dispersants

\begin{tabular}{|c|c|}
\hline Dispersant & Composition \\
\hline Darvan $\mathrm{C}^{\mathrm{a}}$ & Ammonium polymethacrylate \\
\hline Darvan $7^{\mathrm{a}}$ & Sodium polymethacrylate \\
\hline Darvan $811^{\mathrm{a}}$ & Sodium polyacrylate \\
\hline Darvan $821 \mathrm{~A}^{\mathrm{a}}$ & Ammonium polyacrylate \\
\hline APMA $^{\mathrm{b}}$ & Ammonium polymethacrylate \\
\hline Dispex $\mathrm{A} 40^{\mathrm{c}}$ & $\begin{array}{l}\text { Aqueous solution of an acrylic copolymer } \\
\text { (ammonium salt) }\end{array}$ \\
\hline Dispex $\mathrm{G} 40^{\mathrm{c}}$ & $\begin{array}{l}\text { Aqueous solution of an acrylic copolymer } \\
\text { (sodium salt) }\end{array}$ \\
\hline Dispex GA40 & $\begin{array}{l}\text { Aqueous solution of an acrylic copolymer } \\
\text { (sodium salt) }\end{array}$ \\
\hline Dispex $N 40^{c}$ & $\begin{array}{l}\text { Aqueous solution of an acrylic copolymer } \\
\text { (sodium salt) }\end{array}$ \\
\hline Glascol K1 $1^{\mathrm{c}}$ & Aqueous solution of an acrylic copolymer \\
\hline Calgon $^{\mathrm{d}}$ & Sodium hexametaphosphate \\
\hline $\mathrm{SPP}^{\mathrm{d}}$ & $\begin{array}{l}\text { Tetra-Sodium pyrophosphate } \\
\text { decahydrated }\end{array}$ \\
\hline
\end{tabular}

a R. T Vanderbilt Co. Inc., USA.

b Polysciences Inc., USA.

c Ciba Specialty Chemicals Inc. UK.

d Fluka Chemic GmbH.

\subsection{Electrophoretic measurements}

The electrophoretic mobility of the OHAp particles was determined with a laser Zmaster. Suspensions containing $1.10^{-4}$ wt. $\%$ of OHAp and $1 \mathrm{wt} . \%$ of dispersant were prepared using a $10^{-3} \mathrm{~mol} / 1 \mathrm{KNO}_{3}$ solution. The suspensions were ultrasonically dispersed during 15 $\mathrm{min}$. The measurements of electrophoretic mobility were made as a function of $\mathrm{pH}$ in the range $4-12$ at $20{ }^{\circ} \mathrm{C}$. The $\mathrm{pH}$ adjust was made with $\mathrm{KOH}$ and $\mathrm{HNO}_{3}$ solutions. Zeta potential (ZP) was calculated by using the Smoluchowski equation from electrophoretic mobility measurements. ${ }^{20}$ Each ZP value reported was calculated from the average of five measurements.

\subsection{Sedimentation study}

Sedimentation tests were carried out on 2 vol.\% suspensions of OHAp, using a dispersant concentration of 1 wt. $\%$. The suspensions were dispersed by magnetic stirring during $5 \mathrm{~min}$. followed by ultrasonic treatment for $2 \mathrm{~min}$. An aliquot of $10 \mathrm{ml}$ of the dispersed suspension was poured in a graduated cylinder. The height of the interface between the clear and turbid portions (sedimentation height) was measured after $24 \mathrm{~h}$ and 3 weeks, and the height of sediment accumulated on the bottom of the cylinder was measured after 3 weeks.

\subsection{Slurries preparation}

An aquoeus solution containing 15 wt. $\%$ of methacrylamide (Aldrich) and $N, N^{\prime}$-methylenebisacrylamide 
(Aldrich) monomers in 6/1 ratio was used as dispersing vehicle. The slurries were prepared by mixing, in a first stage, the dispersant and the monomeric solution, then the resultant solution was added to the OHAp powder and all components were mixed in a planetary ball mill.

\subsection{Viscosity measurements}

Viscosity was measured using a Haake ReoStress RS75 rheometer with a cone-plaque system. Measurements were performed at $20^{\circ} \mathrm{C}$, in the shear rate range of $1-700 \mathrm{~s}^{-1}$.

\section{Results and discussion}

\subsection{Powder characterisation}

The XRD patterns of OHAp powders calcined at different temperatures are shown in Fig. 1. The patterns of samples calcined at temperatures of $1100{ }^{\circ} \mathrm{C}$ and lower showed only the characteristic reflections of OHAp. ${ }^{21}$ Two additional maxima at $37.4^{\circ}$ and $53.9^{\circ} 2 \theta$ were observed in the sample calcined at $1200{ }^{\circ} \mathrm{C}$. They were attributed to $\mathrm{CaO}^{22}$ formed by decomposition of carbonateapatite. The content of $\mathrm{CaO}$, determined by the Rietveld method, was 1.3 wt.\%.

Fig. 2a shows the specific surface area as function of calcination temperature. The higher the temperature, the lower the surface area. A great decrease took place for powder calcined at temperature between 600 and $900{ }^{\circ} \mathrm{C}$. The surface area decreased from $52 \mathrm{~m}^{2} / \mathrm{g}$, for the powder dried at $105{ }^{\circ} \mathrm{C}$, to $1 \mathrm{~m}^{2} / \mathrm{g}$ for the powder calcined at $1200{ }^{\circ} \mathrm{C}$.

The morphology of OHAp powder did not changed significantly by calcination at temperatures between 600 and $1000{ }^{\circ} \mathrm{C}$, in spite of surface area decreased from 47 to $11 \mathrm{~m}^{2} / \mathrm{g}$. Apparently, only the surface of the particles became smoother as the calcination temperature was

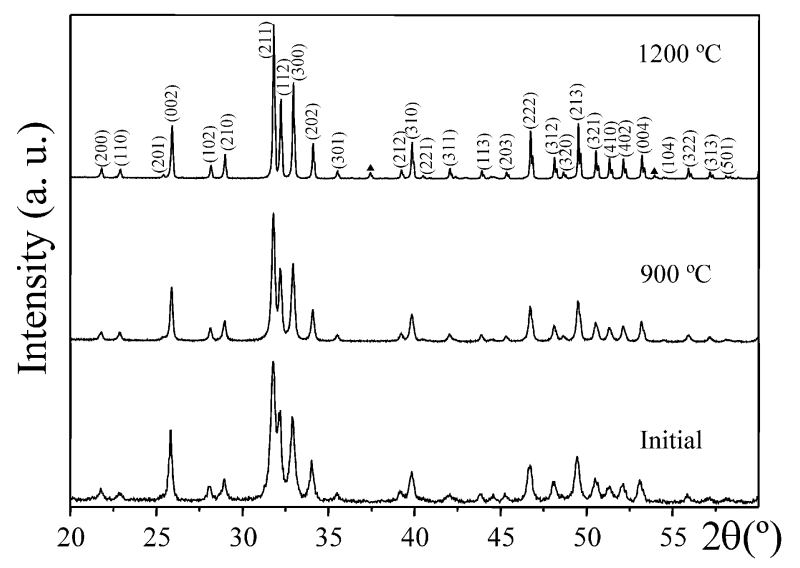

Fig. 1. XRD patterns of OHAp powders calcined at different temperatures. Indexed maxima correspond to OHAp and $\boldsymbol{\Delta}$ to $\mathrm{CaO}$.
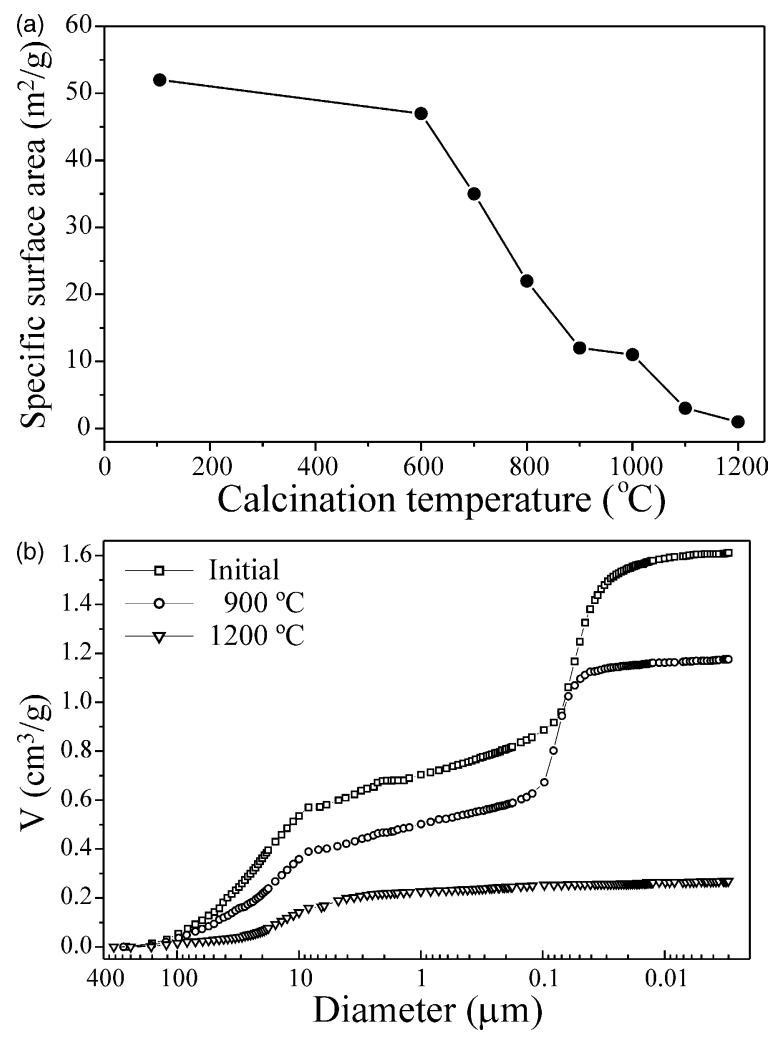

Fig. 2. Influence of the heat treatment on (a) the specific surface area (BET) and on (b) the porosity of OHAp powders.

increased. However, the particles size considerably increased, because of partial sintering, when calcination temperature of 1100 and $1200^{\circ} \mathrm{C}$ were employed.

The curves of intruded $\mathrm{Hg}$ volume versus pore diameter for samples calcined at different temperatures are shown in Fig. 2b. Samples heated at 105 and $900{ }^{\circ} \mathrm{C}$ displayed two contributions to the intruded $\mathrm{Hg}$ volume, whereas sample calcined at $1200{ }^{\circ} \mathrm{C}$ showed only the first step. The first step corresponds to inter-agglomerates pores and the second one is due to pores between

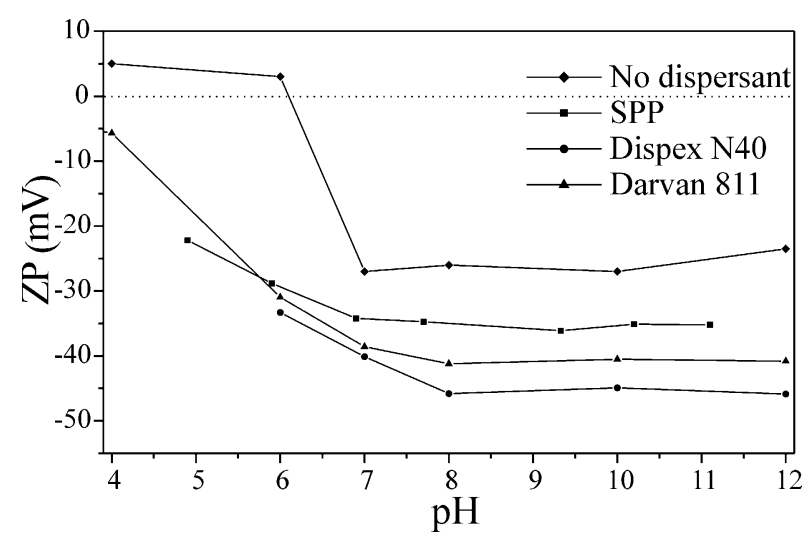

Fig. 3. Influence of $\mathrm{pH}$ and dispersants on the zeta potential of OHAp particles. 
particles forming agglomerates. The shape of the intruded $\mathrm{Hg}$ volume curve of sample calcined at $1200{ }^{\circ} \mathrm{C}$ is characteristic of a non-porous powder.

In order to obtain colloidal slurries it is necessary to use powders with low surface area, because powders with high surface area tend to form undesirable agglomerates. On the other hand, powders with low surface area (calcined at high temperature) have higher density and grain size. This could make the bigger particles to settle out resulting in density heterogeneity. In addition, the increase of particle size and the diminishing of surface area difficult the final sintering. Therefore, a compromise between these aspects must be reached. Previous studies have shown that OHAp powders with surface area around $10 \mathrm{~m}^{2} / \mathrm{g}$ are suitable to prepare slurries with a solid content of $50 \mathrm{vol.} \% .^{23}$ Therefore, powder calcined at $900{ }^{\circ} \mathrm{C}$ was selected for initial experiments.

\subsection{Dispersant selection}

In order to prepare dispersed slurries, it is necessary to increase the repulsive forces between particles. In general, the dispersion of slurries can be achieved through electrostatic, steric or electro-steric mechanisms. ${ }^{24}$ Electrostatic stabilisation is accomplished by generating global charges with equal sign and high enough on the surface of the particles. Steric stabilisation is achieved by adsorption of polymeric additives, which form protective colloids. Electro-steric stabilisation is a combination of electrostatic and steric mechanisms. It requires the presence of adsorbed polyelectrolytes and significant electrical double-layer repulsion..$^{25-27}$ The $\mathrm{pH}$ and the ionic strength of the solvent are very important parameters influencing phenomena of surface charging and adsorption. $\mathrm{pH}$ affects both, the surface charge of the particles, and the dissociation degree and conformation of the adsorbed polyelectrolytes.

\subsubsection{Electrophoretic measurements}

The electrophoretic measurements are related to the electric repulsive forces that a dispersant provokes between particles. Therefore a study of influence of dispersant and $\mathrm{pH}$ on $\mathrm{ZP}$ was carried out. Fig. 3 shows the curves of $\mathrm{ZP}$ as a function of $\mathrm{pH}$ for OHAp calcined at $900{ }^{\circ} \mathrm{C}$ without dispersant and with three of the studied dispersants. All dispersants exhibited a similar behaviour, i.e., they increased the absolute value of $\mathrm{ZP}$, which represents an increase of the repulsive forces between particles. Absolute value of ZP and dispersing efficacy of all dispersants under study increases with $\mathrm{pH}$ and almost all reached the maximum at $\mathrm{pH} 8$, then keeping almost constant until $\mathrm{pH}$ 12. The $\mathrm{ZP}$ values obtained at $\mathrm{pH} 8$ for all the dispersants studied are shown in Table 2.
Table 2

Zeta potential of OHAp particles with different dispersants at $\mathrm{pH}=8$

\begin{tabular}{lc}
\hline Dispersant & ZP $(\mathrm{mV})$ \\
\hline SPP & $-34.7 \pm 0.8$ \\
Darvan 821A & $-36.2 \pm 0.8$ \\
Darvan 7 & $-37.9 \pm 0.6$ \\
Calgon & $-38.1 \pm 0.7$ \\
APMA & $-39.0 \pm 0.8$ \\
Dispex G40 & $-39.6 \pm 0.5$ \\
Darvan 811 & $-41.2 \pm 0.6$ \\
Dispex GA40 & $-43.5 \pm 0.2$ \\
Glascol K11 & $-43.9 \pm 0.3$ \\
Darvan C & $-44.1 \pm 0.9$ \\
Dispex N40 & $-45.8 \pm 0.8$ \\
Dispex A40 & $-46.6 \pm 0.5$ \\
\hline
\end{tabular}

Taking into account that higher $\mathrm{ZP}$ values were obtained at $\mathrm{pH} \geqslant 8$, and that for anionic polyelectrolytes having carboxylic groups, the maximum dissociation occurs at basic $\mathrm{pH},{ }^{28,29}$ the $\mathrm{pH}$ of the slurries was adjusted at 8.5 in the rest of the study.

\subsubsection{Sedimentation study}

The results of this study are shown in Fig. 4. It was observed that dispersants Darvan 811, Dispex GA40 and Glaskol K11 were the most effective in preventing sedimentation. These dispersants provide maximal deflocculation of particles (highest sedimentation height) and disintegration of the particle aggregates (lowest sediment height).

The results of ZP and the sedimentation study showed that although various dispersants produce high absolute values of $\mathrm{ZP}$, only three of them induced a good behaviour of sedimentation. Therefore, besides the electrostatic repulsion, the steric repulsion must play an important role.

\subsubsection{Viscosity measurements}

Slurries with 30 vol. $\%$ of OHAp calcined at $900{ }^{\circ} \mathrm{C}$ were prepared using the three dispersants previously selected (Darvan 811, Dispex GA40 or Glaskol K11). The concentration of dispersant was varied between 1 and $8 \mathrm{mg} / \mathrm{m}^{2}$ and the viscosity was measured as an indicator of the dispersion state of the slurries. It is usually assumed that the best state of dispersion and stability of a slurry corresponds to the minimum viscosity of the suspension. Darvan 811 and Glaskol K11 produced fluid slurries, however, Dispex GA40 yielded foamed slurry not suitable to produce dense ceramics bodies. The results for Darvan 811 and Glaskol K11 are shown in Fig. 5a. It was observed that the lowest viscosity was obtained when Darvan 811 was used. For both dispersants the lowest viscosity was obtained for intermediate concentrations of dispersant $\left(\approx 0.9\right.$ to $\left.3.8 \mathrm{mg} / \mathrm{m}^{2}\right)$. At low amounts of 


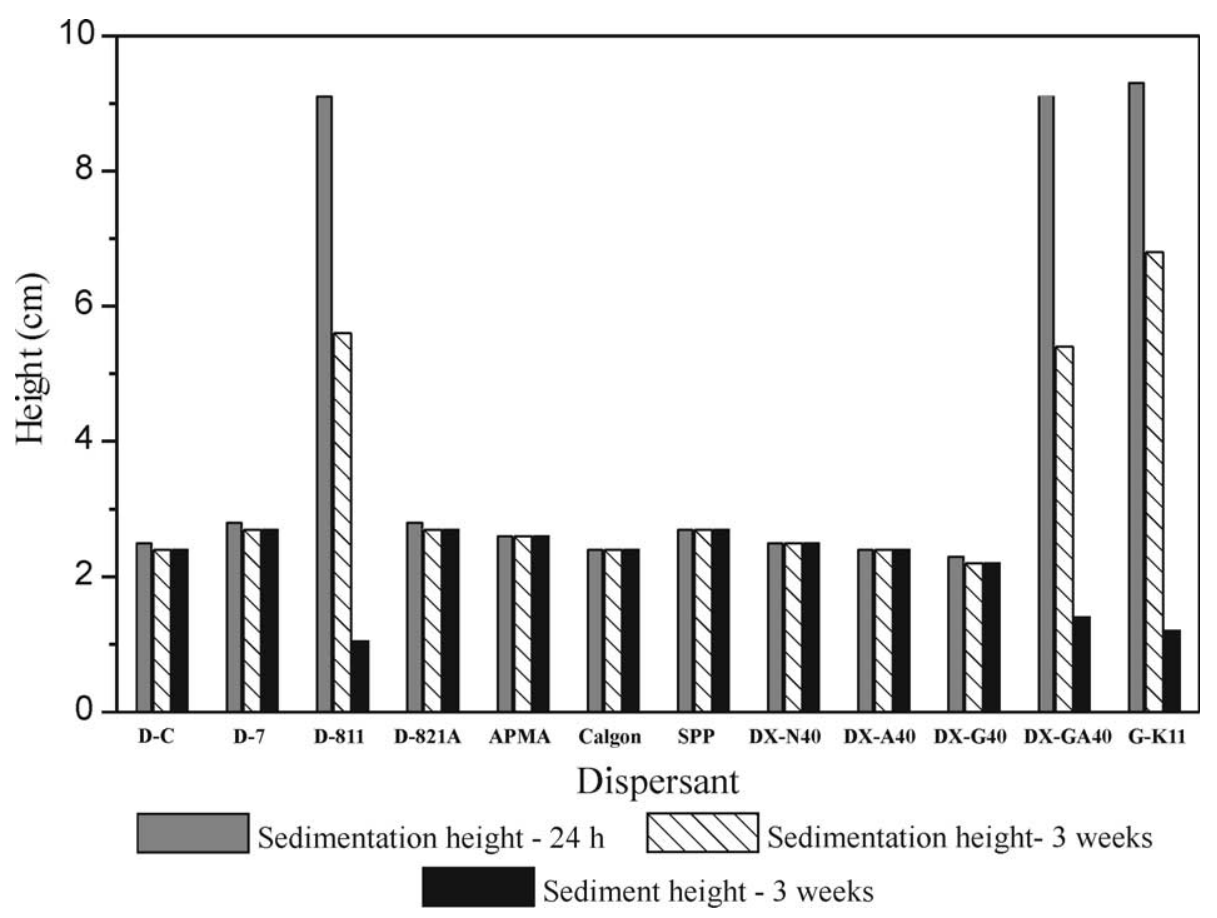

Fig. 4. Sedimentation behaviour of OHAp slurries with different dispersants (D-Darvan, DX-Dispex).

dispersant, the electric double layer is not enough to achieve an effective interparticle repulsion and prevails the attraction between them. When a higher amount of dispersant is added, the electric double layer is compressed by too high electrolyte concentration and the electrostatic repulsion is less effective and, therefore, the viscosity increases. Besides, an excess of non-adsorbed polyelectrolyte in solution could provoke a viscosity increase.
In order to study the content of admissible solid, slurries containing 40 and 50 vol. \%, of OHAp calcined at $900{ }^{\circ} \mathrm{C}$, were prepared using a concentration of Darvan 811 of $2.3 \mathrm{mg} / \mathrm{m}^{2}$. The slurries with 40 vol.\% were liquid but the viscosity was higher $\left(0.70 \mathrm{~Pa} \mathrm{~s}\right.$ at $\left.200 \mathrm{~s}^{-1}\right)$, while when a solid concentration of 50 vol.\% was used the slurries had a paste-like consistency.

For this reason, powders calcined at higher temperatures (lower surface area) were employed and the influence

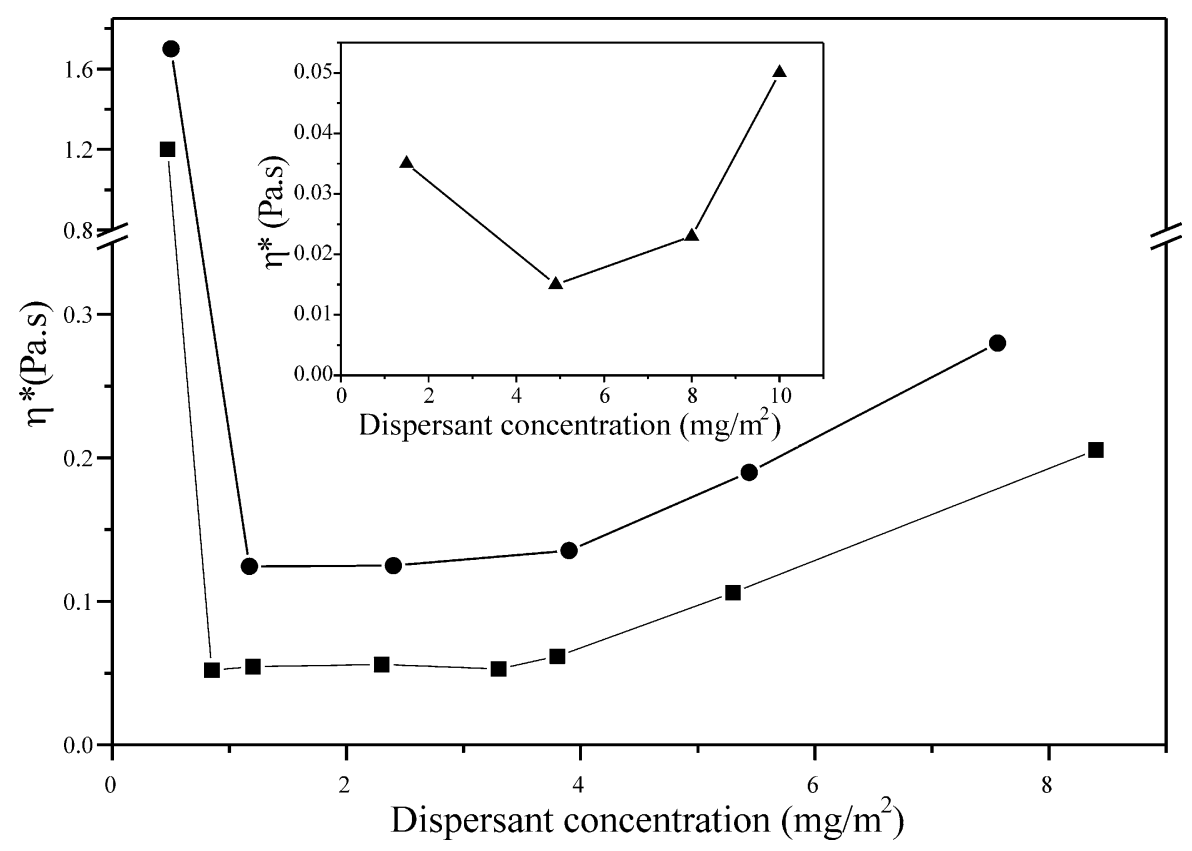

Fig. 5. Influence of dispersant concentration ( Glascoll K11, Darvan 811) on (a) viscosity of slurries with 30 vol. $\%$ of OHAp calcined at $900{ }^{\circ} \mathrm{C}$ and on (b) viscosity of slurries with 30 vol. $\%$ of OHAp calcined at $1200{ }^{\circ} \mathrm{C}$ with Darvan 811 . (shear rate $200 \mathrm{~s}^{-1}$ ). 
of the calcination temperature on slurries viscosity was studied. Slurries with 40 vol. \% were prepared from OHAp powders calcined at temperatures ranging between 1000 and $1200{ }^{\circ} \mathrm{C}$ using a concentration of Darvan 811 equal to $2.3 \mathrm{mg} / \mathrm{m}^{2}$.

The variation of the apparent viscosity of the slurries as function of the calcination temperature is shown in Fig. 6. It was observed a great decrease of viscosity when OHAp powder calcined from 1000 to $1100{ }^{\circ} \mathrm{C}$ were used, being those slurries prepared with powders calcined at 1100 and $1200{ }^{\circ} \mathrm{C}$ very fluid.

Afterwards, slurries with a higher solid content (50 vol. \%) were prepared with OHAp powder calcined at 1000,1100 and $1200{ }^{\circ} \mathrm{C}$. Slurries prepared with OHAp calcined at 1000 and $1100{ }^{\circ} \mathrm{C}$ had a paste-like consistency whereas the one prepared with OHAp $1200{ }^{\circ} \mathrm{C}$ was liquid. Therefore, only powders calcined at $1200^{\circ} \mathrm{C}$ were suitable to prepare suspensions with a solid content $\geqslant 50$ vol. $\%$.

The OHAp calcined at $900{ }^{\circ} \mathrm{C}$ was a carbonateapatite. Whereas by calcining at $1200{ }^{\circ} \mathrm{C}$ a mixture of hydroxyapatite and calcium oxide was obtained. Differences in phase composition may induce changes in the dispersant adsorption and therefore different amount of dispersant would be necessary to obtain fluid slurries. Fig. 5b shows the apparent viscosity versus dispersant concentration for slurries containing 30 vol. $\%$ of OHAp calcined at $1200{ }^{\circ} \mathrm{C}$. Comparing this results which those obtained for OHAp calcined at $900{ }^{\circ} \mathrm{C}$ (Fig. 5a), it can be observed that the lowest viscosity was obtained for different concentration of D811 for OHAp calcined at 900 and $1200{ }^{\circ} \mathrm{C}$. The minimum viscosity was reached with concentrations of D811 in the range of 0.9 to 3.8 $\mathrm{mg} / \mathrm{m}^{2}$ with powder calcined at $900{ }^{\circ} \mathrm{C}$ whereas for OHAp calcined at $1200{ }^{\circ} \mathrm{C}$ the best concentration was $\approx 5 \mathrm{mg} / \mathrm{m}^{2}$. This fact may be related to the presence of $\mathrm{CaO}$ in the powder calcined at $1200^{\circ} \mathrm{C}$. In the presence of water $\mathrm{CaO}$ quickly transforms into $\mathrm{Ca}(\mathrm{OH})_{2}$ which is slightly soluble and provide $\mathrm{Ca}^{2+}$ ions to the medium.

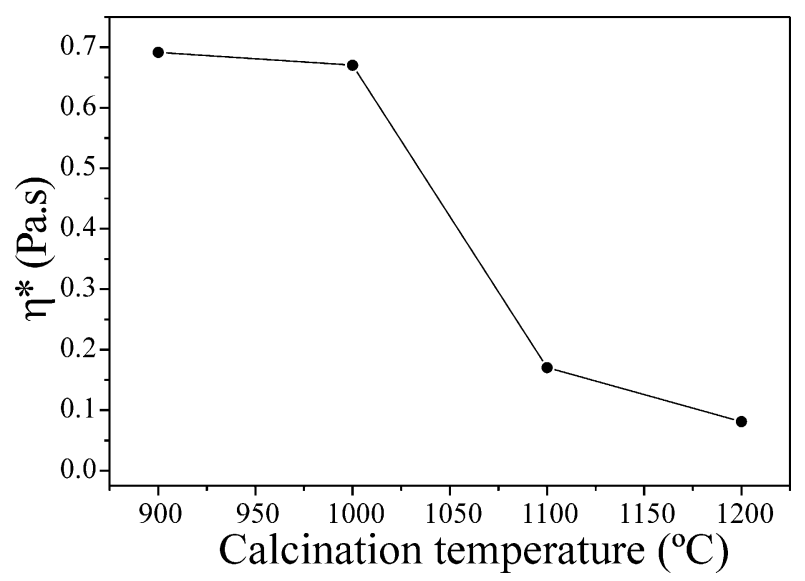

Fig. 6. Influence of the calcination temperature on the viscosity of slurries containing $40 \mathrm{vol} \% \%$ of OHAp (shear rate $200 \mathrm{~s}^{-1}$ ).
Several studies ${ }^{30-32}$ have showed that $\mathrm{Ca}^{2+}$ ions increase the adsorption of poly(acrylic acid) in slurries of alumina, titania and calcium carbonate and this effect has been related to interactions of $\mathrm{Ca}^{2+}$ with the polyelectrolyte.

The slurries made from powder calcined at $1200{ }^{\circ} \mathrm{C}$ were always more fluid than those made from powder calcined at $900{ }^{\circ} \mathrm{C}$ for all concentrations of dispersant studied. Therefore, besides chemical composition and surface area of the powder another factor influencing slurry fluidity should be present. Part of the liquid in a slurry is immobilised inside the pores of agglomerates, therefore the effective volume of liquid would be higher in powder with lower porosity. As can be observed in Fig $2 b$ powder porosity decreased significantly as the calcination temperature increased. Therefore the viscosity of powder calcined at $1200{ }^{\circ} \mathrm{C}$ would be lower.

\subsection{Mixing time}

The homogenisation of OHAp powder and the dispersing liquid was made in a planetary ball mill. During this process, homogenisation of components and powder dispersion take place. Therefore, it is important to know the time to reach the best state of dispersion. It was evaluated by measurement of viscosity in slurries with 50 vol. $\%$ off OHAp calcined at $1200{ }^{\circ} \mathrm{C}$. The results are shown in Fig. 7. It can be observed that the viscosity increased significantly with the time of mixing. If the increase of viscosity during milling were due to a decrease of particle size (increasing of the specific surface area) or to degradation of the dispersant, ${ }^{33}$ a higher amount of dispersant would be necessary. Therefore, after each mixing time more dispersant was added. However, not decrease of viscosity was observed when more dispersant was added. That result shows that another aspects are affecting the dispersant adsorption and the slurries stability, which increase with the mixing time. Taking into account all these data, the best mixing

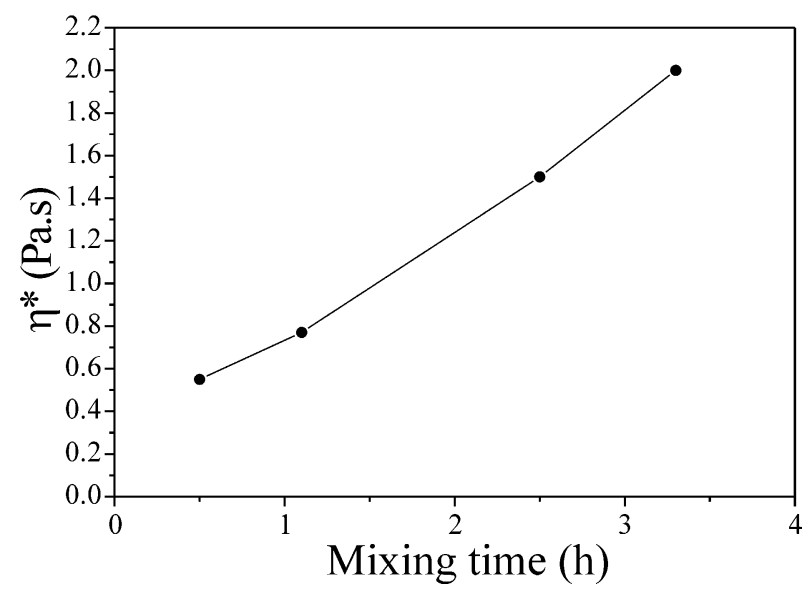

Fig. 7. Viscosity versus time of mixing for slurries with 50 vol. $\%$ of OHAp calcined at $1200{ }^{\circ} \mathrm{C}$ (shear rate $200 \mathrm{~s}^{-1}$ ). 
time for dispersing the slurries was considered to be 30 min, time that was employed for the rest of the experiments in this work.

\subsection{Influence of particle size}

The particle size and its distribution is another aspect that plays an important role in the rheological behaviour of suspensions. For this reason, the OHAp powders were dry milled for different times (2, 4 and $20 \mathrm{~h}$ ) before preparing the slurries. The particle size distribution and the surface area were determined after milling. The influence of milling time of OHAp powder on slurry viscosity was evaluated.

The particle size distribution, determined by sedimentation, and morphology are shown in Fig. 8. It was observed that the average particle size decreased from 62 to $3 \mu \mathrm{m}$ and the surface area increased from $\approx 1$ to $3.5 \mathrm{mg} / \mathrm{m}^{2}$ after $20 \mathrm{~h}$ of milling. The curves obtained for different milling times show wide distributions of particle size. Before milling the powders were formed by aggregates of many particles with size ranging between 30 and $0.5 \mu \mathrm{m}$. Particles showed irregular shape, with a wide distribution of sizes. After $4 \mathrm{~h}$ of milling, the size ranged between 5 and $0.2 \mu \mathrm{m}$. After $20 \mathrm{~h}$ aggregates with size around $5 \mu \mathrm{m}$ were observed, however the majority were much smaller, prevailing in number those with size lower than $1 \mu \mathrm{m}$. This powder is a mixture of individualised primary particles and broken aggregates of different size formed during calcination. This kind of distribution can lead to closer packing on the posterior process of consolidation because smaller particles can fit into the interstices between larger particles.

The influence of particle size and its distribution on the viscosity was evaluated for slurries containing 40 vol. \% of OHAp using Darvan 811 as dispersant. Different concentration of dispersant was used in order to study if, during dry milling, changes in the OHAp powder that affect the adsorption of dispersant took place.

It can be observed in Fig. 9 that viscosity of slurries prepared using OHAp milled was lower than that without milling, being the viscosity much lower when powder milled for $20 \mathrm{~h}$ were used. The concentration of dispersant rendering the lowest viscosity was similar for powders milled for different times.

\subsection{Solid content}

The maximum admissible solid content was determined by viscosity measurements using the conditions selected before. Slurries containing between 40 and 60 vol. $\%$ of OHAp calcined at $1200{ }^{\circ} \mathrm{C}$ and milled for $20 \mathrm{~h}$, were studied. The curves of viscosity versus shear rate of this slurries are shown in Fig. 10. The viscosity of the slurries with 40,45 and 50 vol.\% is very low and the

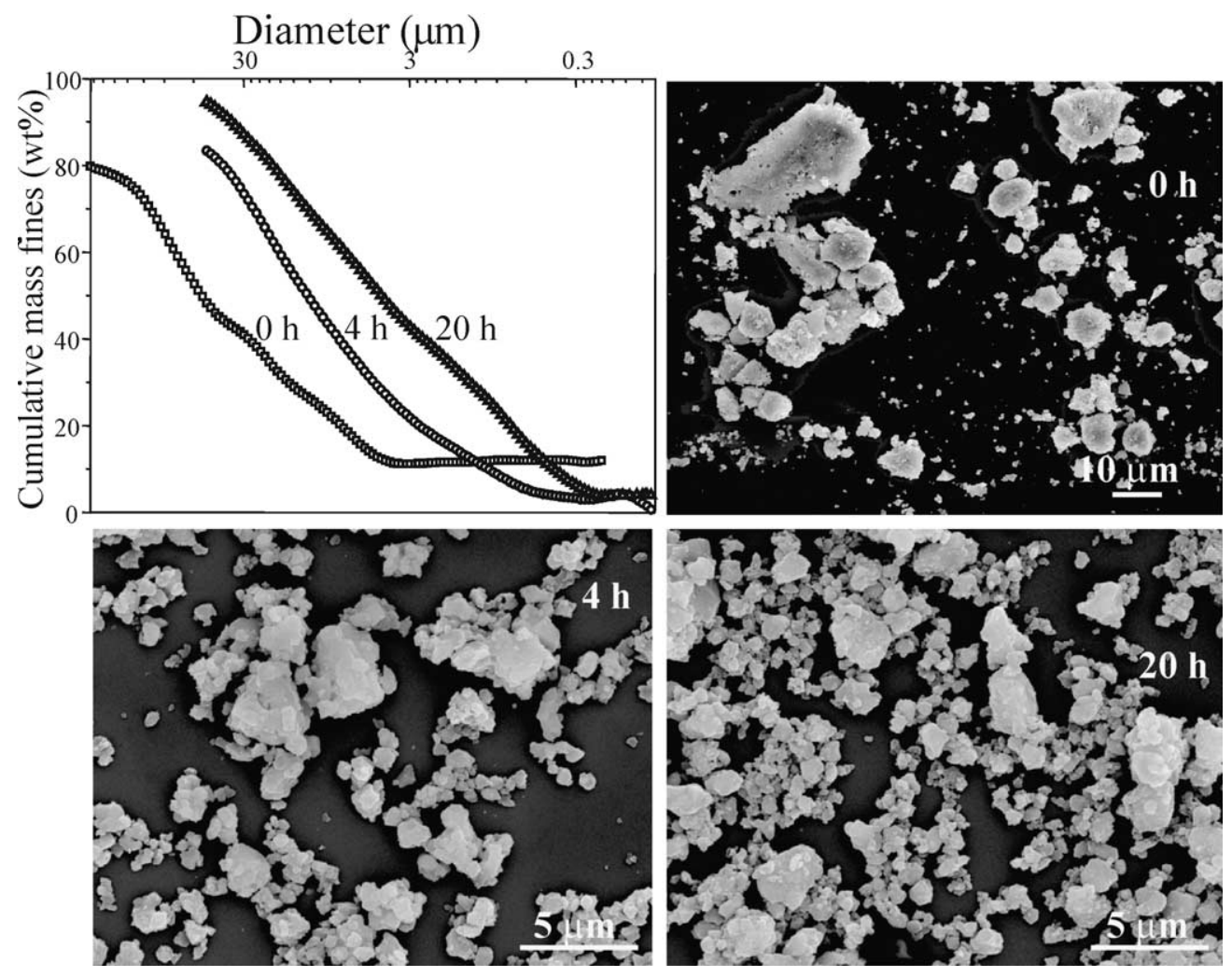

Fig. 8. Particle size distributions and morphology of OHAp powders calcined at $1200{ }^{\circ} \mathrm{C}$ after different milling times. 
suspensions exhibited a Newtonian behaviour. The viscosity of slurries with 55 and 60 vol.\% was higher but they were still fluid and easy to cast into the mould. The slurry with 55 vol. $\%$ show a Newtonian behaviour whereas that with 60 vol.\% show a shear thinning behaviour at low shear rate.

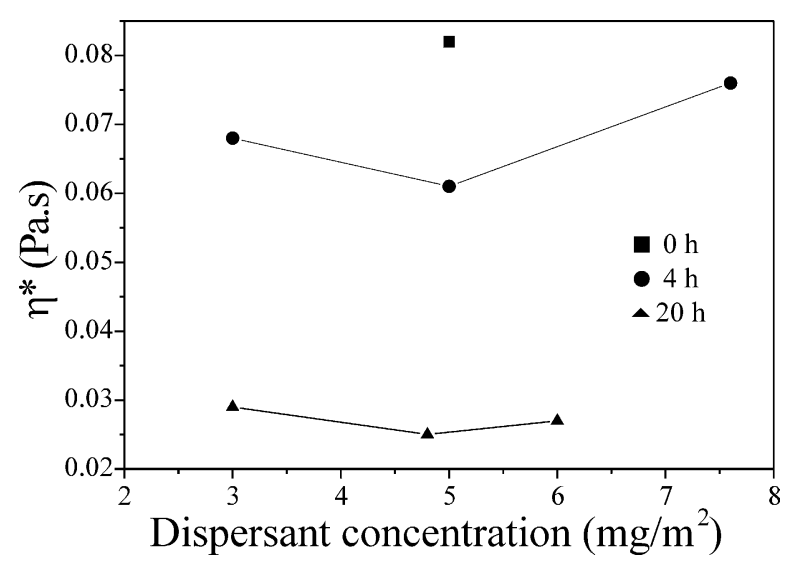

Fig. 9. Influence of dispersant concentration on the viscosity of slurries with 40 vol. $\%$ of OHAp calcined at $1200{ }^{\circ} \mathrm{C}$ milled at different times (shear rate $200 \mathrm{~s}^{-1}$ ).

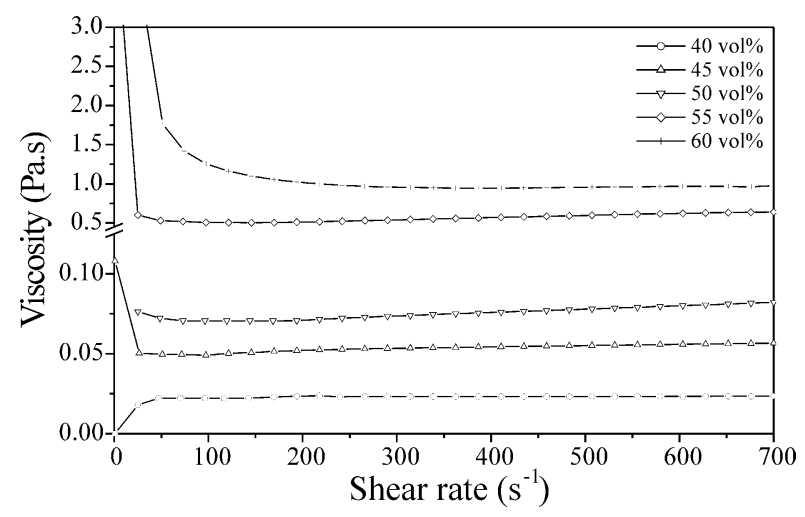

Fig. 10. Viscosity versus shear rate for slurries containing different contents of OHAp calcined at $1200{ }^{\circ} \mathrm{C}$.

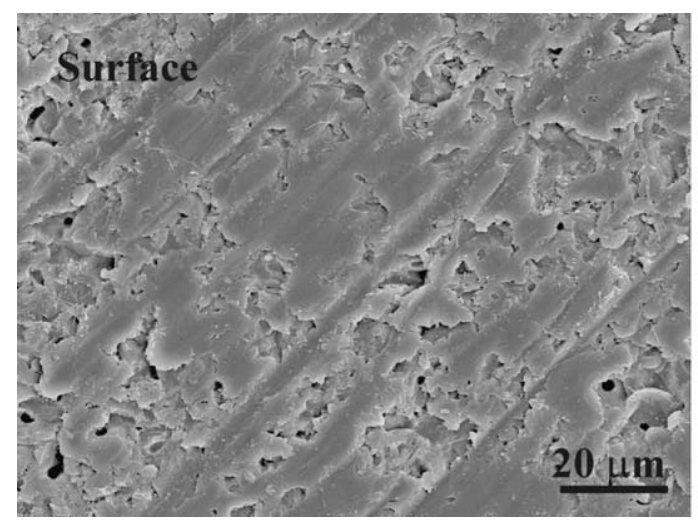

\subsection{Preparation and characterization of ceramic bodies}

Suspensions with a powder concentration of 60 vol.\% were used to cast test pieces. Ammonium persulphate (Aldrich) solution and a $N, N, N^{\prime}, N^{\prime}$ tetramethylene diamine (Aldrich) solution were used as initiator and catalyst, respectively. The amounts added allowed a working time long enough for the necessary manipulation for casting. The slurry was cast into moulds of $55-\mathrm{mm}$ length, $8-\mathrm{mm}$ width, and $5-\mathrm{mm}$ height. The gelification was made at $50{ }^{\circ} \mathrm{C}$. The gelled pieces were carefully dried to avoid cracking. After casting, gelification and drying, very well shaped green bodies were obtained. Neither contraction nor cracking was observed and the pieces showed enough strength to be handled.

The dried pieces were sintered at $900{ }^{\circ} \mathrm{C}\left(1{ }^{\circ} \mathrm{C} / \mathrm{min}\right)$ for $3 \mathrm{~h}$ and, finally, at $1300{ }^{\circ} \mathrm{C}\left(5^{\circ} \mathrm{C} / \mathrm{min}\right)$ during $24 \mathrm{~h}$. The thermal treatment produced a compact ceramic body.

Surface and fracture micrographs (SEM) of pieces prepared after sintering are shown in Fig. 11. The surface is characteristic of compacted ceramics materials. The fracture micrographs show several pores of different size, ranging between 8 and $0.5 \mu \mathrm{m}$, distributed in the ceramic matrix quite regularly. The characteristics of the ceramic bodies obtained are shown in Table 3 . The density of the bodies was determined by mercury intrusion porosimetry. Flexural strength was measured as recommended by the standard MIL-STD-1942, using the four-point configuration in a MTS Bionix 858 equiped with a load cell of $2.5 \mathrm{kN}$. $^{34}$ The indentation

Table 3

Characteristics of the ceramic bodies obtained from a slurry with 60 vol. $\%$ of OHAp

\begin{tabular}{llll}
\hline $\begin{array}{l}\text { Density } \\
\left(\mathrm{g} / \mathrm{cm}^{3}\right)\end{array}$ & $\begin{array}{l}\text { Flexural } \\
\text { strength } \\
(\mathrm{MPa})\end{array}$ & $\begin{array}{l}\text { Elasticity } \\
\text { modulus } \\
(\mathrm{GPa})\end{array}$ & $\begin{array}{l}\text { Vickers } \\
\text { hardness } \\
(\mathrm{HV})\end{array}$ \\
\hline $3.0 \pm 0.1$ & $54 \pm 4$ & $63 \pm 5$ & $240 \pm 26$ \\
\hline
\end{tabular}

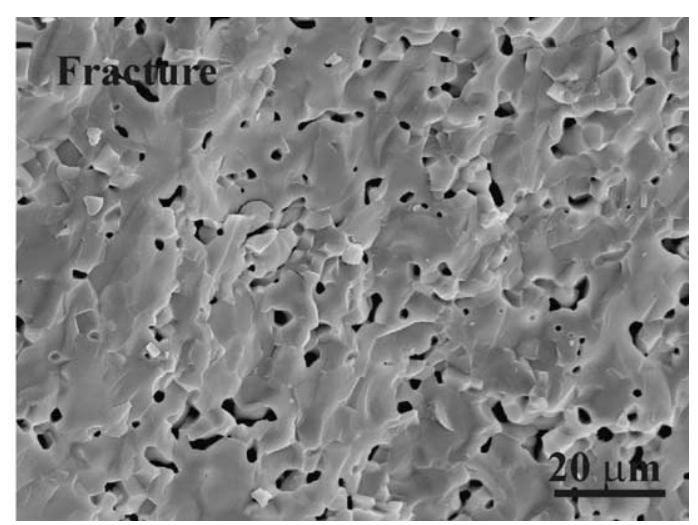

Fig. 11. Surface and fracture microstructure of sintered OHAp pieces obtained from a 60 vol. $\%$ slurry of powder calcined at $1200{ }^{\circ} \mathrm{C}$. 
test was performed in a Matzuzawa microhardness tester, with a Vickers indenter, applying a load of $4.9 \mathrm{~N}$ for $15 \mathrm{~s}$. The mechanical properties were measured after surface polishing.

The mechanical properties of these pieces are within the range of reported for OHAp. ${ }^{35,36}$ The bodies' density was $95 \%$ of the theoretic density. Even thought the powder used to prepare the ceramics bodies was calcined previously at a high temperature $\left(1200{ }^{\circ} \mathrm{C}\right)$, neither settling out nor density heterogeneity was observed. However the pieces density and mechanical properties did not result as higher as expected for a ceramic of OHAp calcined at $1300{ }^{\circ} \mathrm{C}$ during $24 \mathrm{~h}$. This fact must be consequence of the high calcinations temperatures of the initial powder and of presence of $\mathrm{CaO}$ that it is know to affect the sinterability of OHAp. ${ }^{37}$ The mechanical behaviour of the pieces obtained by this method would discuss in another work.

\section{Conclusions}

Dispersed suspensions with high content of OHAp powder (up to 60 vol. $\%$ ) and low viscosity were obtained.

Surface area, porosity and phase composition of the OHAp powder affected significantly the viscosity of slurries. The slurries with the highest concentration of solids were obtained using OHAp calcined at $1200{ }^{\circ} \mathrm{C}$. The concentration of dispersant which provides the minimum viscosity, was different for OHAp calcined at 900 and $1200{ }^{\circ} \mathrm{C}$. The most efficient dispersant selected by electrophoretic, sedimentation and viscosity measurement was Darvan 811.

The viscosity was strongly affected by the time of mixing of slurries, increasing with time. Dry milling during $20 \mathrm{~h}$ produce powder with a broad distribution of particles size, smallest particle size and the lowest viscosity. The slurries with solid concentration of 40 to 55 vol.\% of OHAp calcined at $1200{ }^{\circ} \mathrm{C}$ showed a Newtonian behaviour and the ones with 60 vol.\% show a shear thinning behaviour at low shear rate.

The green bodies prepared had good handling strength and rendered by sintering ceramics bodies with homogeneous microstructure and mechanical properties in the range of that reported for OHAp.

\section{Acknowledgements}

Financial support of CICYT, Spain, through research projects MAT02-0025 and ICI-MEC/PR264/97 are acknowledged. Authors also thank to A. Crespo and M.P Ginebra for carrying out the mechanical test and C.A.I. electron microscopy and C.A.I. X-ray diffraction, UCM, for valuable technical and professional assistance. Ricardo Molina S.A and Ciba Especialidades Químicas S.L. are also acknowledged for kindly supply the dispersants employed in this work.

\section{References}

1. Aoki, H., Science and Medical Applications of Hydroxyapatite. Takayama Press, Tokyo, 1991.

2. Hench, L. L., Bioceramics: from concept to clinic. J. Am. Ceram. Soc., 1991, 74, 1487-1510.

3. De Groot, K., ed., Bioceramics of calcium phosphate99114. CRC Press, Boca Raton, FL, 1983.

4. Rey, C., Calcium Phosphates in Biological and Industrial Systems. Kluwer Academic Publishers, London, 1998.

5. Janney, M. A., Method for Forming Ceramic Powders into Complex Shapes. US Patent 4894194, 1990.

6. Omatete, O. O., Janney, M. A. and Strehlow, R. A., Gelcastinga new ceramic forming process. Am. Ceram. Soc. Bull., 1991, 70, $1641-1649$.

7. Young, A. C., Omatete, O. O., Janney, M. A. and Menchhofer, P. A., Gelcasting of alumina. J. Am. Ceram. Soc., 1991, 74, 612618.

8. Waesche, B. and Steinborn, G., Influence of slip viscosity on the mechanical properties of high purity alumina made by gelcasting. Key. Eng. Mater., 1997, 132-136, 374-377.

9. Sepulveda, P. and Binner, J. G. P., Processing of cellular ceramics by foaming and in situ polymerisation of organic monomers. $J$. Eur. Ceram. Soc., 1999, 19, 2059-2066.

10. Omatete, O. O., Pollinger, J. P. and O'Young, K., Optimization of the gelcasting of a silicon nitride formulation. Ceram. Trans., 1995, 56, 337-343.

11. Ma, L. G., Huang, Y., Yang, J. L., Xie, Z. P., Xu, X. L. and Zhao, J. S., Improving the breakdown strength of rutile capacitor by gelcasting. J. Mater. Sci. Lett., 2001, 20, 1285-1288.

12. Vlajic, M. D. and Krstic, V. D., Strength and machining of gelcast SiC ceramics. J. Mat. Sci., 2002, 37, 2943-2947.

13. Yi, Z. Z., Xie, Z. P., Huang, Y., Ma, J. T. and Cheng, Y. B., Study on gelcasting and properties of recrystallized silicon carbide. Ceram. Int., 2002, 28, 369-376.

14. Omatete, O. O., Blair, A. and Westmoreland, C. G. and Young, A. C., Gelcast zirconia-alumina composites. Ceram. Eng. \& Sci. Proc., 1991, 12, 2084-2094.

15. Liu, X., Huang, Y. and Yang, J., Effect of rheological properties of the suspension on the mechanical strength of $\mathrm{Al}_{2} \mathrm{O}_{3}$ $\mathrm{ZrO}_{2}$ composites prepared by gelcasting. Ceram. Int., 2002, 28, 59-164.

16. Sepulveda, P., Binner, J. G. P., Rogero, S. O., Higa, O. Z. and Brsessiani, J. C., Production of porous hydroxyapatite by the gelcasting of foams and cytotoxic evaluation. J. Biomed. Mater. Res., 2000, 50, 27-34.

17. Lelievre, F., Bernache-Assollant, D. and Chartier, T., Influence of powder characteristics on the rheological behaviour of hydroxyapatite slurries. J. Mater. Sci.: Mater. Med., 1996, 7, 489-494.

18. Toriyama, M., Ravaglioli, A., Krajewski, A., Galassi, C., Roncari, E. and Piancastelli, A., Slip casting of mechanochemically synthesized hydroxyapatite. J. Mater. Sci., 1995, 30, 3216-3221.

19. Yasuda, H. Y., Mahora, S., Umakoshi, Y., Imazato, S. and Ebisu, S., Microestructure and mechanical property of synthesized hydroxyapatite prepared by colloidal process. Biomaterials, 2000, 21, 2045-2049.

20. Hunter, R. J., Zeta potential in colloid science. Academic Press, New York, 1981.

21. Powder Diffraction File, No. 9-432. Data Base Sets 1-49 plus 7086. International Centre for Diffraction Data, 1999. 
22. Powder Diffraction File, No. 43-1001. Data Base Sets 1-49 plus 70-86. International Centre for Diffraction Data, 1999.

23. Rodríguez-Lorenzo, L. M., Vallet-Regí, M. and Ferreira, J. M. F., Colloidal processing of hydroxyapatite. Biomaterials, 2001, 22, 1847-1852.

24. Napper, D. H., Polymeric Stabilization of Colloidal Dispersions. Academic Press, London, 1983.

25. Cesarano, I. I. I. J, Aksay, I. A. and Bleier, A., Stability of aqueous $\alpha-\mathrm{Al}_{2} \mathrm{O}_{3}$ suspensions with poly(methacrylic acid) polyelectrolyte. J. Am. Ceram. Soc., 1988, 71, 250-255.

26. Everett, D. H., Basic Principles of Colloid Science. Royal Society of Chemistry, London, 1988.

27. Lewis, J. A., Colloidal processing of ceramics. J. Am. Ceram. Soc., 2000, 83, 2341-2359.

28. Molyneux, P., Water-Soluble Synthetic Polymers: Properties and Behaviour. Vol II. CRC Press, Boca Raton, FL, 1984.

29. Papenhuijzen, J., Van der Schee, H. A. and Fleer, G. J., Polyelectrolyte adsorption I. A new lattice theory. J. Colloid Interface Sci., 1985, 104, 540-561.

30. Dupont, L., Foissy, A., Mercier, R. and Mottet, B., Effect of calcium ions on the adsorption of polyacrylic acid onto alumina. J. Colloid Interface Sci., 1993, 161, 455-464.
31. Vedula, R. R. and Spences, H. G., Adsorption of poly(acrylic acid) on titania (anatase) and zirconia colloids. Colloids Surf., 1991, 58, 99-110.

32. Foissy, A., El Attar, A. and Lamarche, J. J., Colloid Interface Sci., 1983, 96, 275.

33. Chartier, T., Souchard, S., Baumard, J. F. and Vesteghem, H., Degradation of dispersant during milling. J. Eur. Ceram. Soc., 1996, 16, 1283-1291.

34. MIL-SRD-1942(MR). Flexural Strength of High Performance Ceramics at Ambient Temperature. US. Department of Defense, 1983.

35. Suchanek, W. and Yoshimura, M., Processing and properties of hydroxyapatite-based biomaterials for use as hard tissue replacement implants. J. Mater. Res., 1997, 13, 94-117.

36. Rodriguez-Lorenzo, L. M., Vallet-Regí, M., Ferreira, J. M. F., Ginebra, M. P., Aparicio, C. and Planell, J. A., Hydroxyapatite ceramic bodies with tailored mechanical properties for different applications. J. Biomed. Mater. Res., 2002, 60, 159-166.

37. Royer, A., Viguie, J. C., Heughebaert, M. and Heughebaert, C., Stoichiometry of hydroxyapatite: Influence on the flexural strength. J. Mater. Sci.: Mater. Med., 1993, 4, 76-82. 